\title{
Timing of sexual maturity in female rhesus monkeys (Macaca mulatta) housed outdoors
}

\author{
M. E. Wilson, T. P. Gordon, M. S. Blank, and D. C. Collins* \\ Yerkes Regional Primate Research Center, Field Station, 2409 Collins Hill Road, Lawrenceville, \\ GA 30245 and $^{*}$ Department of Medicine, Emory University, Atlanta, GA 30322, U.S.A.
}

\begin{abstract}
Summary. A comparison of the age and season at first parturition was made for springborn female rhesus monkeys and for females born in the fall to mothers who had been laboratory-housed before being transferred outdoors. Females $(N=9)$ born during the fall had first parturition during the spring and summer, as did all spring-born females $(\mathrm{N}=68)$, and not during the fall as would be predicted if age were the determining factor. A separate analysis of post-menarchial, spring-born females $(\mathrm{N}=5)$ beginning in September at 29 months of age revealed that the ensuing 12 months were characterized by low serum levels of oestradiol $(<50 \mathrm{pg} / \mathrm{ml})$, progesterone $(<1.0$ $\mathrm{ng} / \mathrm{ml})$, LH $(<7.0 \mathrm{ng} / \mathrm{ml})$, and FSH $(<5.50 \mu \mathrm{g} / \mathrm{ml})$. First ovulation subsequently occurred in the fall in all subjects at a mean age of $41.9 \pm 0.1$ months, and was preceded by significant elevations in basal LH and FSH, coincident in time with the transition of summer to fall (September). Female copulatory behaviour was restricted to the period surrounding first ovulation, beginning some 2 weeks before and ceasing within 3 days after the oestradiol peak. The most rapid gain in weight occurred during the summer months before first ovulation, and was associated with significant elevations in serum $\mathrm{GH}$ and prolactin. These data suggest that season may influence the timing of sexual maturation in rhesus monkeys kept outside in such a way that the occurrence of first ovulation is restricted to the fall and winter months.
\end{abstract}

\section{Introduction}

Sexual development in female rhesus monkeys (Macaca mulatta) is associated with significant physiological changes, with maturation completed when a female attains the ability to ovulate, conceive, and maintain pregnancy. In laboratory-housed animals first ovulation is preceded by a rapid gain in weight and typically occurs during the 4th year, some 3-15 months after menarche (van Wagenen, 1952; Foster, 1977; Norman \& Spies, 1981; Resko, Goy, Robinson \& Norman, 1982). The interval between menarche and first normal ovulation, termed 'adolescent sterility', is characterized by anovulatory cycles with extended periods of amenorrhoea and, less frequently, by ovulatory cycles with a short luteal phase (Foster, 1977; Resko et al., 1982).

The timing of maturity is therefore thought to be governed solely by the development of the neuroendocrine-ovarian system which could occur at any age beyond the time of menarche. In addition to the endogenous changes associated with sexual maturation, however, seasonal factors also may modulate the process. Births occur only in the spring and summer months in multiparous and primiparous female rhesus monkeys housed outside (Wilson, Gordon \& Bernstein, 1978; Van Horn, 1980). This pattern of births implies that conceptions are, in turn, seasonally restricted, 
occurring 5.5 months earlier during the fall and winter. Data on animals in controlled laboratory settings with minimal, if any, exposure to outdoor cues indicate that season has no effect on the occurrence of menarche and subsequent maturational events (Resko et al., 1982) or that there is a tendency for menarche (Foster, 1977) and ovulation (Terasawa, Nass, Yeoman, Loose \& Schultz, 1983) to occur during the fall. Given the distribution of births in animals exposed to an outdoor environment, we postulated that season influences the timing of sexual maturation in female rhesus monkeys housed outdoors. We evaluated this hypothesis by (1) examining the age and season of first parturition in fall- and spring-born females and (2) describing the timing of the hormonal, growth, and behavioural changes which occur in post-menarchial monkeys until first conception.

\section{Materials and Methods}

Rhesus monkeys used in the present analysis were housed in $38.1 \times 38.1 \mathrm{~m}$ outdoor compounds with attached indoor quarters. General housing and maintenance have been described previously (Gordon \& Bernstein, 1973). Except for morning observational periods, animals had access to the indoor quarters throughout the day. The indoor quarters had windows to the outside and were artificially lit only during normal daylight hours. The light-dark cycle in these facilities therefore followed the natural photoperiod for this latitude $\left(33^{\circ} 45^{\prime} \mathrm{N}\right)$.

Age and seasonal effects on maturity. The relationship between age, season, and first parturition was examined in a retrospective analysis of 77 colony-born females. Of these, 68 were born during the spring and summer months. The remaining 9 females were born during the fall months to mothers which had recently been transferred from a laboratory environment. All 77 females lived in the outdoor compound environment from birth until sexual maturity. Females were categorized by age at first parturition as 'typical' if birth occurred during the 4th year, and 'early' or 'late' if births occurred during the 3rd or 5th year, respectively (Wilson et al., 1978). Dates of conception were estimated by backdating 168 days from the date of parturition (van Wagenen, 1972).

Physiological and behavioural correlates of maturity. Hormonal, growth and behavioural data were collected from 5 post-menarchial females from 29 months of age through first conception. These 5 females were all born in the spring of 1977. The females were members of a larger social group containing many adult males, females, juveniles and infants. Collection of the data began in September 1979, a time which marks the start of the adult breeding season in our colony (Gordon, 1981), and proceeded for the next 15 months encompassing an adult breeding season (SeptemberMarch), a non-breeding season (April-August) and a portion of the next breeding season (September-December). Capture of the animals for obtaining blood samples and body weights was as previously described (Walker, Gordon \& Wilson, 1982). Blood samples $(5 \mathrm{ml})$ were obtained from unanaesthetized animals according to the following protocol. From September 1979 until January 1980 , animals were captured daily at $11: 00 \mathrm{~h}$ to obtain vaginal swabs to monitor menstruation and twice weekly (Tuesday and Thursday) blood samples for subsequent hormone analyses. From February to August, animals were captured once weekly for venepuncture. Finally, from September to December, blood samples were collected 3 times per week. The occurrence of ovulation was inferred from elevations in serum oestradiol concentrations coincident with gonadotrophin peaks, followed in time by increases in serum progesterone values $>1.0 \mathrm{ng} / \mathrm{ml}$. These criteria were adopted to ensure the detection of normal ovulations and ovulations with a short or inadequate luteal phase (Wilks, Hodgen \& Ross, 1979). Behavioural data were collected for 1-3 h/day, 5-7 days/week, to detect any occurrence of copulations with ejaculation (Wilson, Gordon \& Collins, 1982). In addition, females were weighed once monthly throughout the study period.

Radioimmunoassay's. Serum hormone concentrations were determined by radioimmunoassays. The oestradiol-17 $\beta$ assay, described earlier (Wright, Collins \& Preedy, 1973), utilized a specific 
antiserum against 6-O-carboxymethyloxime-BSA. The sensitivity (defined as twice the s.d. of the zero dose) was $25 \mathrm{pg} / \mathrm{ml}$. Recovery values after extraction exceeded $85 \%$. Between- and within-assay coefficients of variation (CV) were 8.9 and $5.1 \%$ respectively. The progesterone assay utilized a specific antibody against the $11 \alpha$-carboxymethyloxime derivative of progesterone (Wilson et al., 1982). Assay sensitivity was $0.2 \mathrm{ng} / \mathrm{ml}$ and had between- and within-assay CVs of 12.2 and $7.3 \%$ respectively. Recovery values after extraction exceeded $90 \%$. Assay of serum levels of folliclestimulating hormone (FSH) followed the procedure described by Hodgen et al. (1976) and utilized an anti-ovine FSH serum and a rhesus pituitary gonadotrophin preparation, LER 1909-2, as a reference. Assay sensitivity was $2.0 \mu \mathrm{g} / \mathrm{ml}$ and the between- and within-assay CVs were 14.6 and $6.3 \%$, respectively. Serum levels of luteinizing hormone $(\mathrm{LH})$ were assayed as described by Monroe, Peckham, Neill \& Knobil (1970) and utilized a rabbit anti-hCG serum and radioiodinated macaque LH (NICHD rhLH). The sensitivity of the assay was $4 \mathrm{ng} / \mathrm{ml}$, with between- and withinassays CVs of 18.2 and $9.3 \%$ respectively. Because serum samples were limited, only selected samples were assayed for $\mathrm{LH}$. Serum prolactin and growth hormone (GH) were measured as described by Blank, Gordon \& Wilson (1983). The sensitivity of both assays was $1.5 \mathrm{ng} / \mathrm{ml}$. Withinand between-assay CVs were $<9$ and $14 \%$ respectively for both hormones.

Statistical analysis. Grouped data were expressed as mean \pm s.e.m. Maturational data were analysed with analysis of variance models for repeated measures. Data were partitioned into three categories for comparison: (1) 29-34 months of age, i.e. September to February; (2) 35-40 months of age, i.e. March to August; and (3) first ovulation. Data at first ovulation are represented by the mean values from -20 to -3 days before the oestradiol peak. Specific comparisons between means were evaluated with Newman-Kuels tests (Keppel, 1973). Linear relationships were evaluated with Pearson product-moment correlations. Differences between means were evaluated with $t$ tests. All statistical values with a probability of $P<0.05$ were considered significant.

\section{Results}

\section{Season of birth and timing of maturation}

The 68 females born into the colony during the spring and summer months (26 March to 4 August) all had their first parturition during the spring and summer. As shown in Table 1, the age at first parturition for these spring-born females clustered into three categories each having a 12

Table 1. Comparison of the mean age and date ( \pm s.e.m.) of first parturition between fallborn and spring-born female rhesus monkeys

\begin{tabular}{|c|c|c|c|c|c|}
\hline \multirow[b]{2}{*}{$\begin{array}{l}\text { Season of } \\
\text { birth }\end{array}$} & & \multirow[b]{2}{*}{$\begin{array}{c}\text { Date of } \\
\text { birth }\end{array}$} & \multicolumn{3}{|c|}{ First parturition } \\
\hline & & & $\begin{array}{c}\text { Age } \\
\text { (months) }\end{array}$ & Observed date & Expected date* \\
\hline \multirow[t]{3}{*}{ Spring } & $\begin{array}{l}\text { Early } \\
(\mathrm{N}=14)\end{array}$ & $\begin{array}{l}5 \text { May } \\
\text { (6.8 days) }\end{array}$ & $\begin{array}{l}36 \cdot 6 \\
(0 \cdot 3)\end{array}$ & $\begin{array}{l}26 \text { May } \\
\text { (4.6 days) }\end{array}$ & - \\
\hline & $\begin{array}{l}\text { Typical } \\
(\mathrm{N}=49)\end{array}$ & $\begin{array}{l}21 \text { May } \\
\text { (4.7 days) }\end{array}$ & $\begin{array}{c}47 \cdot 4 \\
(0 \cdot 2)\end{array}$ & $\begin{array}{l}5 \text { May } \\
\text { (3.6 days) }\end{array}$ & - \\
\hline & $\begin{array}{l}\text { Late } \\
(\mathrm{N}=5)\end{array}$ & $\begin{array}{l}30 \text { April } \\
\text { (4.9 days) }\end{array}$ & $\begin{array}{l}59 \cdot 4 \\
(0 \cdot 3)\end{array}$ & $\begin{array}{l}17 \text { April } \\
\text { (4.2 days) }\end{array}$ & - \\
\hline \multirow[t]{2}{*}{ Fall } & $\begin{array}{l}\text { Early } \\
(N=1)\end{array}$ & 9 Sept. & $32 \cdot 9$ & 6 June & 27 Sept.* \\
\hline & $\begin{array}{l}\text { Typical } \\
(N=8)\end{array}$ & $\begin{array}{l}22 \text { Sept. } \\
\text { (5.3 days) }\end{array}$ & $\begin{array}{l}43 \cdot 0 \\
(0 \cdot 8)\end{array}$ & $\begin{array}{l}1 \text { May } \\
\text { (4.1 days) }\end{array}$ & 12 Sept. $*$ \\
\hline
\end{tabular}

* Calculated on the basis of age at first parturition for spring-born females. 
months difference. These parturitions imply an ovulation and conception 5.5 months earlier during the fall and winter. The 9 females that were born during the fall ( 31 August to 18 November) also had first parturition during the spring and summer (Table 1). The age at first parturition for the 8 'typical' fall-born females was significantly less than that for the 'typical' spring-born females ( $t=$ 8.47 , d.f. $=55, P<0.05$ ). In a similar fashion, the remaining fall-born female, designated 'early', also had first parturition at an age significantly less than that of her spring-born 'early' counterparts $(\mathrm{z}=6.82, P<0.05$ ). If age had been the only determining factor for the timing of maturation, first parturition would have occurred in early fall for these fall-born females (Table 1). Therefore, regardless of the season of their own birth and subsequent age at maturity, females have their first parturition in the spring and summer.

\section{Physiological and behavioural correlates of maturation}

First ovulation, as indicated by hormonal and behavioural changes (see below), occurred for all 5 females in early fall 1980 ( 10 October to 3 November) at a mean age of $41.9 \pm 0.1$ months. All females exhibited vaginal bleeding by $30.6 \pm 0.8$ months. Since collection of data did not begin until 29 months of age, it is not known whether the first menstruation observed represented menarche. During the 12 months preceding first ovulation, the frequency of menstruations varied among females ( $2 \cdot 8 \pm 1.0$ menses; range $1-6)$.

Changes in serum levels of gonadotrophins, ovarian steroids, and the occurrence of sexual behaviour from September 1979 until first ovulation in fall 1980 are illustrated in Text-fig. 1. Serum levels of FSH and LH were low and generally unchanging throughout the 12 months before rising significantly just before the first ovulation (Table 2). The gradual rise in serum gonadotrophin levels began about 35 days before first ovulation, coincident with the transition from summer to fall (Text-fig. 1).

Table 2. Comparison of mean ( \pm s.e.m.) concentrations of hormones during the postmenarchial period and at first ovulation in rhesus monkeys

\begin{tabular}{|c|c|c|c|}
\hline \multirow[b]{2}{*}{ Age (months) } & \multicolumn{2}{|c|}{ Post-menarche } & \multirow{2}{*}{$\begin{array}{c}\text { First ovulation } \dagger \\
41.9 \pm 0.1\end{array}$} \\
\hline & 29-34 & $35-40$ & \\
\hline Period & Sept.-Feb. & March-Aug. & Oct. \\
\hline FSH $(\mu \mathrm{g} / \mathrm{ml})$ & $4.8 \pm 0.8$ & $4.6 \pm 0.8$ & $* 8.6 \pm 0.6$ \\
\hline $\mathrm{LH}(\mathrm{ng} / \mathrm{ml})$ & $6 \cdot 3 \pm 1 \cdot 2$ & $6.6 \pm 0.7$ & $* 7.7 \pm 0.2$ \\
\hline Oestradiol $(\mathrm{pg} / \mathrm{ml})$ & $47 \cdot 3 \pm 6 \cdot 2$ & $45 \cdot 5 \pm 4 \cdot 1$ & $* 99.8 \pm 10.6$ \\
\hline Progesterone $(\mathrm{ng} / \mathrm{ml})$ & ${ }^{*} 0.90 \pm 0.09$ & $0.70 \pm 0.07$ & $0.52 \pm 0.04$ \\
\hline $\mathrm{GH}(\mathrm{ng} / \mathrm{ml})$ & $11 \cdot 8 \pm 1 \cdot 1$ & $*^{*} 28 \cdot 1 \pm 5 \cdot 0$ & $* 29.9 \pm 2.3$ \\
\hline Prolactin $(\mathrm{ng} / \mathrm{ml})$ & $4 \cdot 8 \pm 0.7$ & $* 21 \cdot 4 \pm 6 \cdot 2$ & $3.6 \pm 0.1$ \\
\hline Body weight change $(\%$ increase $)$ & $8 \cdot 7 \pm 3 \cdot 3$ & $* 34 \cdot 3 \pm 4 \cdot 1$ & \\
\hline
\end{tabular}

$\dagger$ Mean values from -20 to -3 days before the oestradiol peak

* $P<0.05$ compared with values for periods without an asterisk.

Levels of serum oestradiol were also low before first ovulation (Text-fig. 1; Table 2), with individual values ranging from 20 to $80 \mathrm{pg} / \mathrm{ml}$. Sustained elevations were observed only after the gonadotrophin increases in early fall 1980 , with mean levels $>70 \mathrm{pg} / \mathrm{ml}$ attained some 25 days before first ovulation. Serum levels of progesterone were low $(<1.0 \mathrm{ng} / \mathrm{ml})$ before first ovulation, but showed a consistent and significant decline with age from September 1979 (29 months) to August 1980 (40 months) (Text-fig. 1). A comparison of mean values indicated that serum progesterone levels from 29 to 34 months were significantly higher than those from 35 to 40 months or at first ovulation at 41.9 months (Table 2). Therefore, although none of the females ovulated until almost 42 months of age, all showed a small but progressive decline in basal serum progesterone levels before that age. 


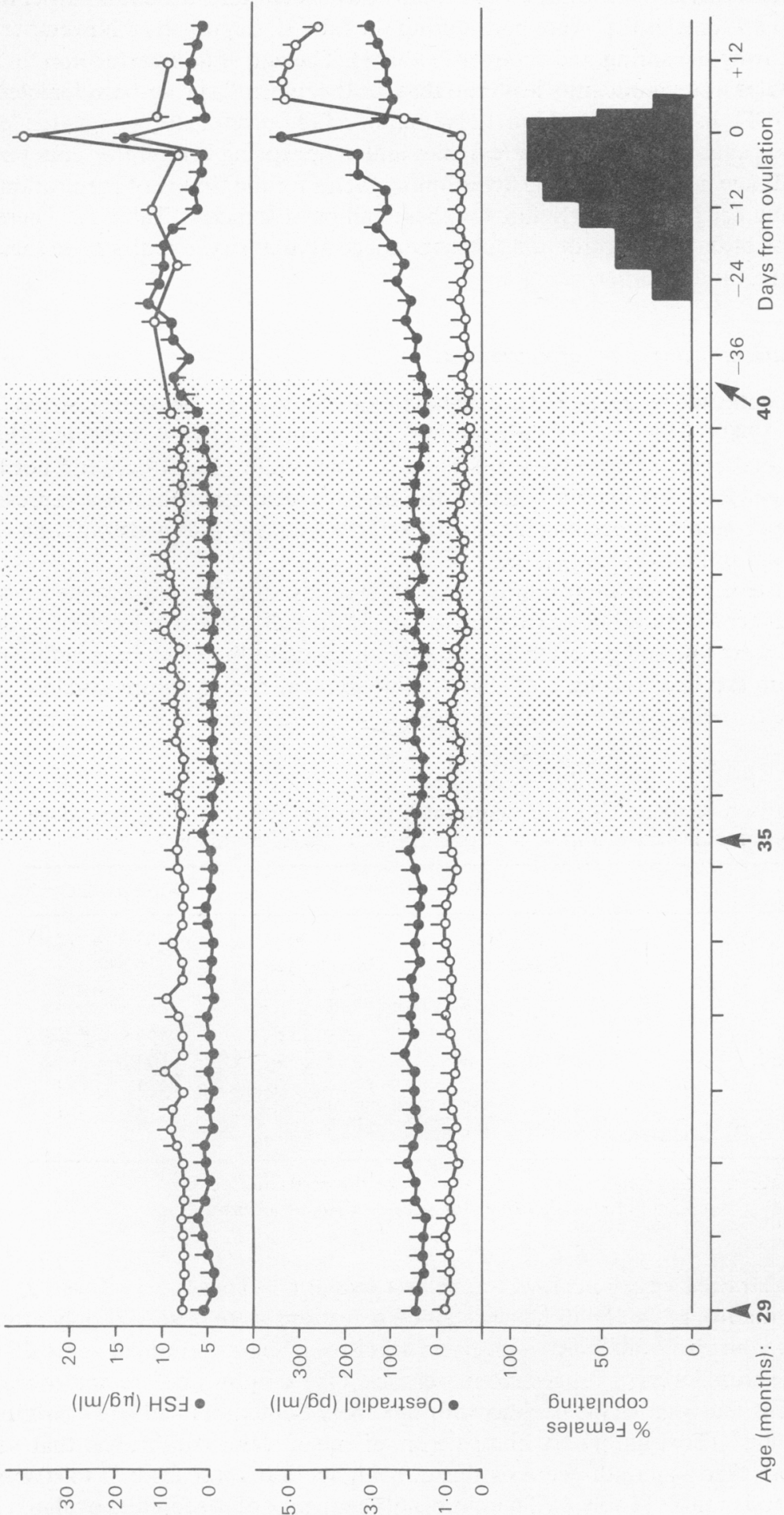

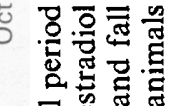
. 氖范 苞苍 के 空悬焉 突要焉 워

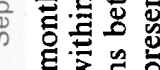
宁苋吾 里骂 इ

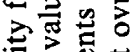
要菏 卷焉. 元 政 过 혼 马可 穼品

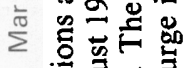

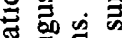

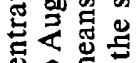
8 空

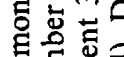
है웡 的

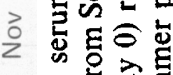
它氞完 क्ष क्ष + 등 동 멸 ㅁำ क $\sum \frac{\pi}{3}$ 。 万娄进

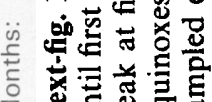

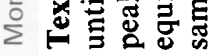
(ןய/6u) $\mathrm{H}\urcorner \mathrm{O}$

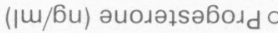


No female copulatory behaviour was observed until $16 \cdot 8( \pm 3.4)$ days before first ovulation (Text-fig. 1). The initiation of copulations for each female was coincident with the rise in serum oestradiol above $80 \mathrm{pg} / \mathrm{ml}$ (group mean \pm s.e.m. $87.8 \pm 2.9 \mathrm{pg} / \mathrm{ml}$ ). Once this sexual activity had begun, copulations by each female occurred daily before abruptly ceasing $3.0 \pm 0.6$ days after the ovulatory oestradiol peak.

Serum concentrations of $\mathrm{GH}$ and prolactin, as well as body weight, changed significantly in the months preceding first ovulation (Text-fig. 2). Serum levels of both hormones increased with age, reaching highest values during the summer months just before first ovulation (Table 2). Concentrations of GH remained elevated throughout the first ovulatory period while prolactin values fell to levels comparable to the fall-winter period 1 year earlier.

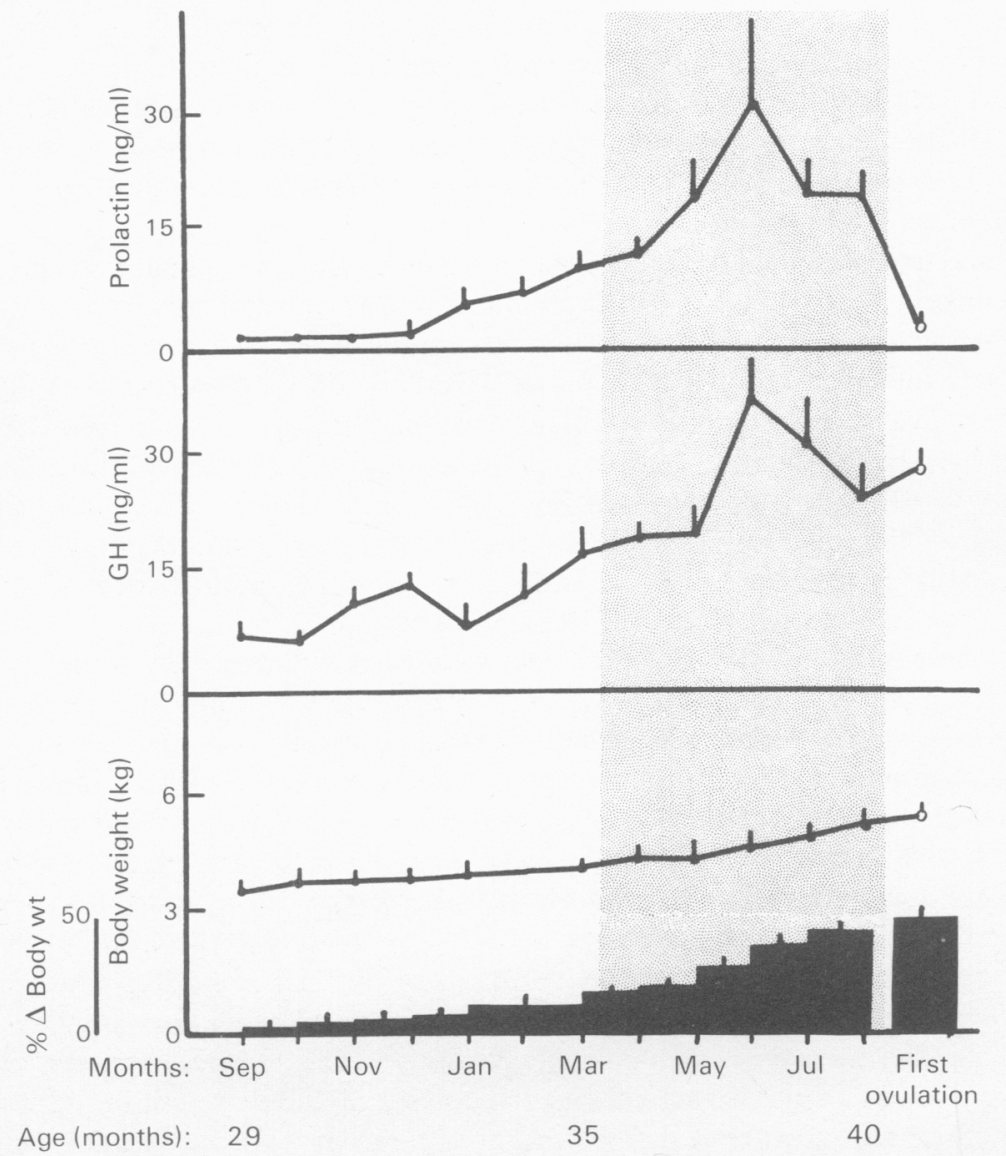

Text-fig. 2. Concentrations (mean \pm s.e.m.) of serum GH and prolactin and body weights during the 12-month period before ovulation in rhesus monkeys. Values at first ovulation, indicated by an open circle, represent the mean for the 14 days before the oestradiol peak. The shaded area corresponds to the spring and summer months.

The significant change in body weight $(\%$ change from September 1979) corresponded in time to changes in circulating GH and prolactin (Text-fig. 2). A significantly greater change in body weight occurred during the spring and summer from 35 to 40 months of age than during the preceding fall and winter at 29-34 months of age (Table 2). In addition, body weight at first ovulation $(5.81 \pm 0.25 \mathrm{~kg})$ was significantly higher than the weight 1 month earlier $(5.65 \pm 0.24 \mathrm{~kg}$; $t=3 \cdot 15$, d.f. $=4, P<0.05$ ). The monthly changes in body weight accompanying maturation were 
positively related to $\mathrm{GH}(r=0.71$, d.f. $=10, P<0.05)$ and prolactin $(r=0.65$, d.f. $=10$, $P<0.05$ ).

All 5 females were impregnated at their first ovulation. Four of these females carried the pregnancy to term with an interval between the ovulatory oestradiol peak and parturition of 170.5 $\pm 2 \cdot 2$ days. Age at first parturition for these females was $47.6 \pm 0.3$ months, which is the typical age at first parturition for spring-born females in the colony (see Table 1).

\section{Discussion}

The present analysis indicates that the timing of sexual maturation in female rhesus monkeys is influenced by season. First parturition, the endpoint in the chain of events from ovulation, conception and pregnancy, occurs during the spring and summer in spring-born and fall-born females rather than at a specific age. Furthermore, although females may mature at different rates, as indicated by the different ages at first parturition, the process is modulated by season with births being restricted to the spring and summer. This seasonal occurrence of first parturition reflects an ovulation the previous fall or winter.

The behavioural and hormonal data from the post-menarchial females support the conclusion that, in rhesus monkeys housed outside, first ovulation as well as conception is seasonally restricted. We have previously demonstrated that, in this environment, female copulatory behaviour is confined to the late follicular-periovulatory period (Gordon, 1981; Wilson et al., 1982) and is a reliable indicator of ovulation (Walker et al., 1982). This relationship was supported in the present analysis also, because female copulatory behaviour was limited to a period of about 2 weeks that was associated with the endocrine events at first ovulation in the fall. Significant elevation in pituitary and ovarian hormones, indicative of follicular maturation and impending ovulation, did not occur in the monkeys in the present study until some 41 months of age at the transition from summer to fall.

Significant increases in serum GH and prolactin occurred during the spring and summer months before first ovulation, and these were positively related to the rapid weight gains that occurred during this period. Serum GH remained elevated throughout first ovulation whereas serum levels of prolactin fell to levels observed the previous fall. Elevations in serum GH may not only influence growth rates (Blizzard et al., 1974) but also may be directly involved in maturation of the reproductive system (Advis, White \& Ojeda, 1980; Ramaley \& Phares, 1982). In rodents serum prolactin levels also rise before first ovulation (Döhler \& Wuttke, 1974). Indeed, hyperprolactinaemia induced in immature rats results in precocious puberty (Advis \& Ojeda, 1978). In addition, the rise in serum prolactin in lambs exposed to long days $(16 \mathrm{~L}: 8 \mathrm{D})$ is associated with a more rapid gain in weight per unit of food eaten, suggesting that photoperiod may interact with prolactin to influence weight gain during puberty (Schanbacher \& Crouse, 1981). Therefore, as has been shown in rodents, GH and prolactin may be actively involved in sexual development in rhesus monkeys, not only in terms of somatic growth but also possibly in maturation of the neuroendocrine system. It is not possible to determine whether the endocrine changes observed before first ovulation by the animals in the present study reflect merely advancing age or are modulated by seasonal events. But these data, coupled with the analysis of maturation in spring-born and fall-born females, suggest that the events accompanying first ovulation in rhesus kept outside are influenced by seasonal changes.

Previous work from laboratory-housed rhesus monkeys suggests that the timing of maturation is not influenced by external cues but is simply a function of endogenous changes (Foster, 1977; Resko et al., 1982). Other data on laboratory-housed rhesus indicate that $85 \%(\mathrm{~N}=53)$ of first ovulations are restricted to the months of October-January (Terasawa et al., 1983). A distribution such as this could reflect an age-related effect or a clustering due to some variable independent of age. Since laboratory conditions are typically $12 \mathrm{~L}: 12 \mathrm{D}$ with constant temperature, humidity and 
minimal, if any, exposure to outdoor environmental cues, the mere tendency of a seasonal occurrence in first ovulation suggests that some endogenous circannual rhythm (Gwinner, 1981) may be controlling the timing of puberty. Such an endogenous rhythm, not entrained by environmental cues, accounts for the variation in serum LH and the annual reproductive cycle observed in ground squirrels (Zucker \& Licht, 1983). However, our data suggest that environmental variables play an important role in the timing of maturation, as indicated by the occurrence of first parturition in the spring for fall-born and spring-born females and the direct observation of first ovulation in the fall.

All 5 females in the present analysis had normal luteal function at first ovulation based on serum progesterone levels. This finding contrasts with observations from laboratory-housed rhesus in which some initial ovulations are characterized by abnormal luteal function (Foster, 1977; Resko et al., 1982). Similar periods of abnormal reproductive function before fertility onset is reported for young female marmosets (Callithrix jacchus; Abbott \& Hearn, 1978), chimpanzees (Pan troglodytes; Young \& Yerkes, 1943), and women (Metcalf, Skidmore, Lowry \& Mackenzie, 1983). The occurrence of such abnormalities in laboratory-housed monkeys may be due to environmental influences, analogous to the abnormal ovulations observed when lambs are prematurely exposed to a photoperiod which stimulates the occurrence of ovulations (Foster, 1983). For rhesus monkeys, then, some aspect of the spring and summer months may inhibit or suppress ovulations while the fall and winter months may induce or stimulate the occurrence of ovulations. In the months following menarche, females in a laboratory environment may experience an increase in gonadotrophin secretion sufficient to stimulate folliculogenesis and ovulation but, given their developmental age, insufficient to maintain normal luteal function. Support for an inhibitory influence of the spring and summer months is evident from a comparison of body weight at first ovulation for animals in the present analysis $(5.81 \pm 0.61 \mathrm{~kg})$ and body weight at first ovulation for animals in a laboratory environment $(4.69 \pm 0.42 \mathrm{~kg}, \mathrm{~N}=5:$ Norman \& Spies, 1981). The animals housed outdoors reached the weight of their laboratory counterparts in midsummer (Text-fig. 2) but nevertheless ovulated in the fall at a significantly heavier weight $(t=-3.02$, d.f. $=8, P<0.05)$. This observation supports the notion that environmental factors may suppress ovulation despite the attainment of a critical degree of development. Thus, unless females are able to ovulate and conceive in the winter months immediately following menarche, as approximately $20 \%$ of our colony females do ('early' groups; Table 1), ovulation would be suppressed until the next fall period. It is obvious that exposure to a seasonal environment is not necessary for the completion of maturation. Rather, an outdoor environment may delay first ovulation. The effect of this seasonal inhibition may function to ensure that, when a female does ovulate for the first time, she is mature enough both endocrinologically and morphologically to support the ensuing pregnancy.

If seasonal changes do modulate the timing of sexual maturation in rhesus monkeys, two basic issues must be addressed: (1) identification of the critical environmental cue(s) which suppress(es) first ovulation until the fall months following menarche, and (2) identification of the site within the hypothalamic-pituitary-ovarian system where the seasonal influence is mediated. It seems reasonable to assume that the environmental variables which restrict ovulations to the fall and winter months in adult females housed outside also restrict the occurrence of first ovulation to the same period in post-menarchial females.

We thank D. Chikazawa, B. Groepper and S. Lackey for technical assistance; L. Wright for editorial assistance; and Dr M. Walker for helpful comments; the National Hormone and Pituitary Program (NIAMDD) and the Contraceptive Development Branch, Center for Population Research, NICHD for materials for the LH and FSH assays; and Dr H. G. Friesen, Winnipeg, Manitoba, for the materials for the GH and prolactin assays. The work was supported by NIH grants HD 05942 and RR00165. 


\section{References}

Abbott, D.H. \& Hearn, J.P. (1978) Physical, hormonal and behavioural aspects of sexual development in the marmoset monkey, (Callithrix jacchus). J. Reprod. Fert. 53, 155-166.

Advis, J.P. \& Ojeda, S.R. (1978) Hyperprolactinemiainduced precocious puberty in the female rat: ovarian site of action. Endocrinology 103, 924-935.

Advis, J.P., White, S.S. \& Ojeda, S.R. (1980) Activation of GH short-loop negative feedback delays in the female rat. Endocrinology 108, 1343-1352.

Blank, M.S., Gordon, T.P. \& Wilson, M.E. (1983) Effects of capture and venipuncture on serum levels of prolactin, growth hormone, and cortisol in outdoor compound-housed female rhesus monkeys (Macaca mulatta). Acta endocr., Copenh. 102, 190-195.

Blizzard, R.M., Thompson, R.G., Bughdassarian, A., Kowarski, A., Migeon, C.J. \& Rodriguez, A. (1974) The interrelationship of steroids, growth hormone, and other hormones on pubertal growth. In Control of the Onset of Puberty, pp. 342-359. Eds M. M. Grumbach, G. D. Graves \& F. E. Meyer. John Wiley, New York.

Döhler, K.D. \& Wuttke, W. (1974) Serum LH, FSH, prolactin and progesterone from birth to puberty in female and male rats. Endocrinology 94, 1003-1008.

Foster, D.L. (1977) Luteinizing hormone and progesterone secretion during sexual maturation of the rhesus monkey: short luteal phases during initial menstrual cycles. Biol. Reprod. 17, 584-590.

Foster, D.L. (1983) Photoperiod and sexual maturation of the female lamb: early exposure to short days perturbs estradiol feedback inhibition of luteinizing hormone secretion and produces abnormal ovarian cycles. Endocrinology 112, 11-17.

Gordon, T.P. (1981) Reproductive behavior in the rhesus monkey: social and endocrine variables. Am. Zool. 21, 185-195.

Gordon, T.P. \& Bernstein, I.S. (1973) Seasonal variation in sexual behavior in all male rhesus troops. $A m . J$. phys. Anthrop. 38, 221-227.

Gwinner, E. (1981) Circannual system. In Handbook of Behavioral Neurobiology, vol. 4: Biological Rhythms, pp. 391-410. Ed. J. Aschoff. Plenum Press, New York.

Hodgen, G.D., Wilks, J.W., Vaitukaitis, J. L., Chen, H., Papkoff, H. \& Ross, G.T. (1976) A new radioimmunoassay for follicle-stimulating hormone in macaques: ovulatory menstrual cycles. Endocrinology 99, 137-145.

Keppel, G. (1973) Design and Analysis. Prentice-Hall, Englewood Cliffs.

Metcalf, M.G., Skidmore, D.S., Lowry, G.F. \& Mackenzie, J.A. (1983) Incidence of ovulation in the years after menarche. J. Endocr. 97, 213-219.

Monroe, S.E., Peckham, W.D., Neill, J.D. \& Knobil, E. (1970) A radioimmunoassay for rhesus monkey luteinizing hormone (RhLH). Endocrinology 86, $1012-1018$.
Norman, R.L. \& Spies, H.G. (1981) Brain lesions in infant female rhesus monkeys: effects on menarche and first ovulation and on diurnal rhythms of prolactin and cortisol. Endocrinology 108, 1723-1729.

Ramaley, J.A. \& Phares, C.D. (1982) Regulation of gonadotropin secretion in the prepubertal period. Neuroendocrinology 35, 439-448.

Resko, J.A., Goy, R.W., Robinson, J.A. \& Norman, R.L. (1982) The pubescent rhesus monkey: some characteristics of the menstrual cycle. Biol. Reprod. 27, 354-361.

Schanbacher, B.D. \& Crouse, J.D. (1981) Photoperiodic regulation of growth: a photosensitive phase during the light-dark cycle. Am. J. Physiol. 241, E1-E5.

Terasawa, E., Nass, T.E., Yeoman, R.R., Loose, M.D. \& Schultz, N.J. (1983) Hypothalamic control of puberty in the female rhesus monkey. In Neuroendocrine Aspects of Reproduction. Eds R. M. Brenner \& C. H. Phoenix. Academic Press, New York.

Van Horn, R.N. (1980) Seasonal reproductive patterns in primates. Prog. Reprod. Biol. 5, 181-221.

van Wagenen, G. (1952) Age at menarche of the laboratory rhesus monkey. Anat. Rec. 112, 436.

van Wagenen, G. (1972) Vital statistics from a breeding colony: reproduction and pregnancy outcome in Macaca mulatta. J. med. Primatol. 1, 3-28.

Walker, M.L., Gordon, T.P. \& Wilson, M.E. (1982) Reproductive performance in capture-acclimated female rhesus monkeys (Macaca mulatta). J. med. Primatol. 11, 291-302.

Wilks, J.W., Hodgen, G.D. \& Ross, G.T. (1979) Endocrine characteristics of ovulatory and anovulatory menstrual cycles in the rhesus monkey. In Human Ovulation, pp. 205-218. Ed. E. S. E. Hafez. Elsevier/ North-Holland Biomedical Press, Amsterdam.

Wilson, M.E., Gordon, T.P. \& Bernstein, I.S. (1978) Timing of births and reproductive success in rhesus monkey social groups. J. med. Primatol. 7, 202-212.

Wilson, M.E., Gordon, T.P. \& Collins, D.C. (1982) Variations in ovarian steroids associated with the annual mating period in female rhesus monkeys (Macaca mulatta). Biol. Reprod. 27, 530-539.

Wright, K., Collins, D.C. \& Preedy, J.R.K. (1973) Comparative specificity of antisera raised against estrone, estradiol-17\% and estriol using 6-O-carboxymethyloxime bovine serum albumin derivatives. Steroids 21, 755-769.

Young, W.C. \& Yerkes, R.M. (1943) Factors influencing the reproductive cycle in the chimpanzee: the period of adolescent sterility and related problems. Endocrinology 33, 121-154.

Zucker, I. \& Licht, P. (1983) Circannual and seasonal variations in plasma luteinizing levels of ovariectomized ground squirrels (Spermophilus lateralis). Biol. Reprod. 28, 178-185.

Received 16 August 1983 